\title{
Effect of energy concentration on the efficiency of betaine and chromium picolinate as dietary supplements for fattening pigs
}

\author{
J. Urbańczyk, E. Hanczakowska and M. Świątkiewicz
}

\author{
Research Institute of Animal Production, \\ Department of Animal Nutrition \\ 32-083 Balice, Poland
}

(Received 19 May 2000; revised version 18 April 2001; accepted 7 August 2001)

\begin{abstract}
The influence of feed energy concentration on the effect of betaine and chromium picolinate added to feeds, either separately or together, on fattening performance, carcass quality and some blood biochemical indicators was investigated in an experiment involving 128 pigs fattened from about 30 to $113 \mathrm{~kg}$ body weight assigned to 4 groups.

The animals given feed with an increased energy content achieved $38 \mathrm{~g}$ better daily weight gains in the first period of fattening, and at the end of fattening their carcasses were similar to those of animals that received the diet with a lower energy concentration.

The results of the experiment showed that the supplements improved fattening performance, especially in animals given chronium picolinate $(902 \mathrm{~g}$ vs $857 \mathrm{~g}$ of body weight gain in the experimental and control groups, respectively). This effect was especially distinct in pigs fed diets with higher energy concentrations. They also improved their leanness from 56.0 to $57.5 \%$ and slightly decreased their backfat thickness. The combined supplement of betaine and chromium picolinate proved inefficient both for fattening and slaughter traits, although it decreased blood cholesterol, especially its LDL fraction by $9 \%$.

Gilts had lower weight gains than barrows and better resuits of post-slaughter evaluation regardless of the supplement used.
\end{abstract}

KEY WORDS: fattening pigs, feed energy, betaine, chromium picolinate 


\section{INTRODUCTION}

The effects of supplementing diets with betaine or organic chromium compounds are highly variable. This concerns both the fattening performance of pigs and post-slaughter evaluation of carcasses, which were shown to vary markedly even in studies by the same authors (Lawrence et al., 1995; Lindemann et al., 1995; Matthews et al., 1998; Urbańczyk et al., 1998a). Supplementation efficiency was also shown to be affected by the level of dietary lysine and methionine (Lawrence et al., 1995; Betafin Briefing, 1996), energy and protein concentrations (Haydon et al., 1995; Matthews et al., 1998) and ad libitum or restricted feeding (Cho et al., 1998; Hanczakowska et al., 1999). Cera and Schinckel (1995), Tilley (1995) and Urbańczyk et al. (1996) observed that gilts and barrows have different reactions to betaine and to chromium supplements. To a certain extent, supplementation efficiency can also be affected by genotype (Page et al., 1993) and even by environmental conditions (Mowat, 1993). Lawrence et al. (1995) found that dietary betaine supplements for pigs increased loin eye area. In the studies of Cadogan et al. (1993), betaine decreased backfat thickness, while Haydon et al. (1995) demonstrated increased backfat thickness and decreased loin eye area.

Varying results were also obtained for body weight gains, which in many studies were more favourable when betaine was supplemented (Haydon et al., 1995; Matthews et al., 1998). However, this was not observed by Cadogan et al. (1993) and Hanczakowska et al. (1999)

These inconsistencies also apply to the efficiency of various chromium supplements (Wenk et al., 1995; Urbańczyk ct al., 1998b) and betaine and organic chromium compounds used together (Le Mieux, 1996; Urbańczyk, 1997; Hanczakowska et al., 1999).

These incompatible results justify the need to explain the effect of some of the above-mentioned factors on the efficiency of betaine and chromium picolinate supplements, especially when used together, in the fattening of pigs.

The aim of this study was to determine the effect of energy concentration in feeds on the efficiency of betaine and chromium picolinate used separately and together, on fattening performance, carcass quality and on some biochemical parameters of blood.

\section{MATERIAL AND METHODS}

The experiment was carried out in a three-factorial design involving 128 fattening pigs assigned to 4 groups of 32 pigs each (half gilts and half barrows). The 
animals were derived from F1 gilts (Polish Landrace $\mathrm{x}$ Polish Large White) mated to a boar of the Polish hybrid line 990 .

Experimental design

Type of supplement - Group I - no supplement

- Group II - $2 \mathrm{~kg} / \mathrm{t}$ of betaine (Betafin BCR 97\%)

- Group III - $200 \mathrm{mg} / \mathrm{t} \mathrm{Cr}$ as chromium picolinate

- Group IV - $2 \mathrm{~kg}$ betaine and $200 \mathrm{mg} / \mathrm{t} \mathrm{Cr}$ as chromium picolinate

Energy level - low energy

- high energy

Sex

- gilts

- barrows

In each group, half of the gilts and half of the barrows received low-energy feeds without fat and the other half of the animals was given feeds containing $6 \%$ post-refining fatty acids of rape oil, rich in unsaturated acids. The experimental feeds were produced according to the composition shown in Table 1.

The pigs were kept on litter in groups (4 pigs per each pen) and fed ad libitum from Domino self-feeders. Each pen had a nipple drinker to which the animals had free access.

The experiment was conducted from an average body weight of about $30 \mathrm{~kg}$ to $113 \mathrm{~kg}$. Venous blood was collected at the same time of the day at about $100 \mathrm{~kg}$ body weight (BW) to determine glucose with an Accutrend glucometer. At the end of fattening, all of the animals were slaughtered and their right halfcarcasses were dissected according to the methods applied at Pig Progeny Testing Stations (State of Pig Breeding, 1995). Blood for analysis was collected during slaughter from the vena jugularis. With the exception of total cholesterol, the other biochemical indicators of blood serum were determined enzymatically using a Beckman DU 640 spectrophotometer and Cormay Pointe Scientific and POCH diagnostic kits. Total cholesterol was determined enzymatically according to Allain et al. (1994) and the HDL fraction according to Warrick et al. (1982). Chemical analyses of feeds and estimation of amino acid contents were conducted using standard methods (AOAC, 1990). The SAS (1988) statistical software package was used for statistical analysis. 
TABLE 1

Composition and nutritive value of feed mixtures, $\%$

\begin{tabular}{|c|c|c|c|c|}
\hline \multirow[b]{2}{*}{ Item } & \multicolumn{2}{|c|}{ Low energy } & \multicolumn{2}{|c|}{ Iligh energy } \\
\hline & $\begin{array}{c}\text { Grower } \\
30-60 \mathrm{~kg} \mathrm{BW}\end{array}$ & $\begin{array}{c}\text { Finsher } \\
60-113 \mathrm{~kg} \mathrm{BW}\end{array}$ & $\begin{array}{c}\text { Grower } \\
30-60 \mathrm{~kg} \mathrm{BW}\end{array}$ & $\begin{array}{c}\text { Finsher } \\
60-113 \mathrm{~kg} \mathrm{BW}\end{array}$ \\
\hline Ground barley & 76.05 & 80.05 & 67.95 & 72.05 \\
\hline Soyabean meal & 14.00 & 11.00 & 16.00 & 13.00 \\
\hline Meat-and-bone meal & 3.00 & 2.00 & 3.00 & 2.00 \\
\hline Wheat bran & 5.00 & 5.00 & 5.00 & 5.00 \\
\hline Post refining fatty acids & - & - & 6.00 & 6.00 \\
\hline Limestone & 0.50 & 0.50 & 0.50 & 0.50 \\
\hline Fodder phosphate & 0.50 & 0.50 & 0.50 & 0.50 \\
\hline Salt & 0.30 & 0.30 & 0.30 & 0.30 \\
\hline Premix* & 0.50 & 0.50 & 0.50 & 0.50 \\
\hline L-lysine $(98 \%)$ & 0.15 & 0.15 & 0.25 & 0.15 \\
\hline \multicolumn{5}{|l|}{ In $I \mathrm{~kg}$ of feed } \\
\hline metabolizable energy, MJ & 12.49 & 12.43 & 13.11 & 13.20 \\
\hline crude protein, $\%$ & 16.58 & 15.19 & 16.65 & 15.28 \\
\hline ether extract, $\%$ & 1.59 & 1.53 & 7.20 & 7.14 \\
\hline crude fibre, $\%$ & 4.73 & 4.80 & 4.43 & 4.50 \\
\hline$N$-free extractives, $\% / \%$ & 59.92 & 60.67 & 55.03 & 56.91 \\
\hline lysine, $\%$ & 0.94 & 0.85 & 0.96 & 0.87 \\
\hline methinonie + cystine, $\%$ & 0.59 & 0.56 & 0.58 & 0.55 \\
\hline
\end{tabular}

* Premix PT-1 (Grower)

Premix PT-2 (Finisher)

$\begin{array}{lll}\text { Composition of Premixes : } & \text { PT-1 } & \text { PT-2 } \\ \text { Vitamin A, IU } & 800.000 & 600.000 \\ \text { Vitamin D 3, IU } & 100.000 & 100.000 \\ \text { Vitamin K 3, g } & 0.1 & 0.1 \\ \text { Vitamin B 2, g } & 0.1 & 0.1 \\ \text { Vitamin B 12, g } & 0.002 & 0.0012 \\ \text { Ca pantotenate, g } & 0.8 & - \\ \text { Mg, g } & 3.0 & 4.0 \\ \text { Zn, g } & 2.0 & 3.0 \\ \text { Flavomycinc, g } & 1.0 & 1.0 \\ \text { Antioxidant, g } & 20.0 & 20.0 \\ \text { Filler, g } & \text { to } 1000.0 & \text { to } 1000.0\end{array}$




\section{RESULTS}

\section{Fattening performance}

Feed intake was affected by the energy concentration in feed, and the differences were highly significant in both the second period of fattening $(6.9 \%)$ and for the entire fattening period $(6.0 \%)$. Mean daily feed intake by pigs depended on the dietary supplement used (Table 2). During the entire fattening period, feed intake by animals given betaine and chromium picolinate together was significantly lower than feed intake by control pigs. There was also a highly significant relationship between feed intake and sex of pigs. Daily feed intake by barrows was an average of 4.5 and $7.3 \%$ higher than by gilts in the first and second fattening periods, respectively.

Mean daily weight gains depended on the energy concentration, i.e. on the content of post-refining fatty acids in feed (Table 2). Daily weight gains of the animals that received more concentrated feed were 39 (4.8\%), $17(1.9 \%)$ and $24 \mathrm{~g}$ $(2.8 \%)$ better in the first and second periods of fattening and for the whole fattening period, respectively. The results were significant only for the first period of fattening. The effect of energy concentration on daily weight gains of pigs treated with betaine or chromium picolinate is shown in Figure 1. The effect of the studied supplements in mixtures with a low energy concentration was non-significant, whereas a higher energy concentration was significant only in the case of chromium picolinate. Animals receiving this supplement gained $82 \mathrm{~g}$ more than without additives. Betaine supplementation of pig feeds proved efficient only in the first period of fattening ( $23 \mathrm{~g}$; Table 2 ), with no significant differences in relation
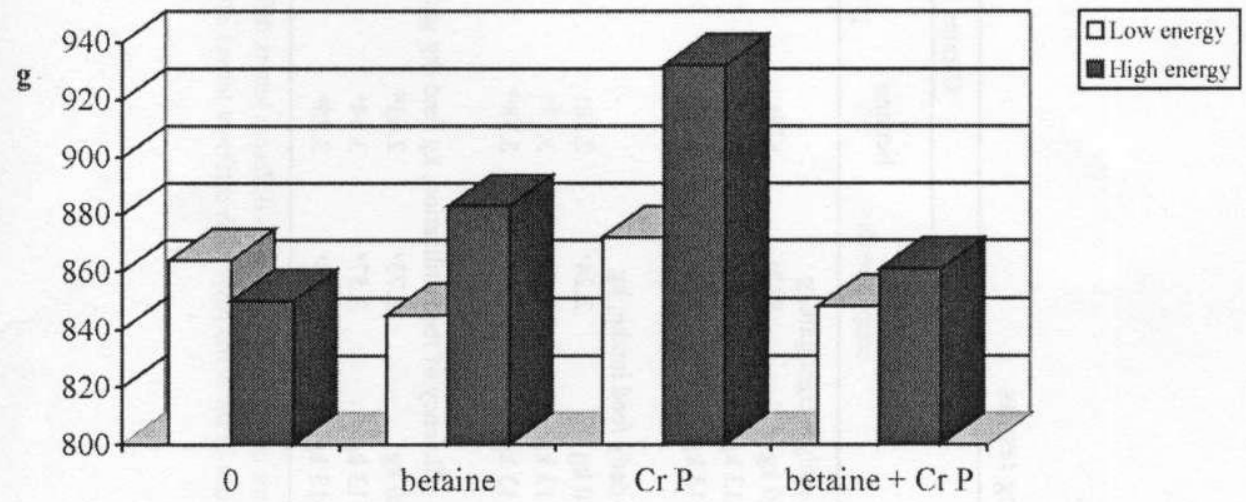

Figure 1. Effect of energy concetration in feeds on daily weight gains of pigs fed betaine or chromium picolinate supplements (period of fattening $30-113 \mathrm{~kg}$ ) 
TABLE 2

Fattening results

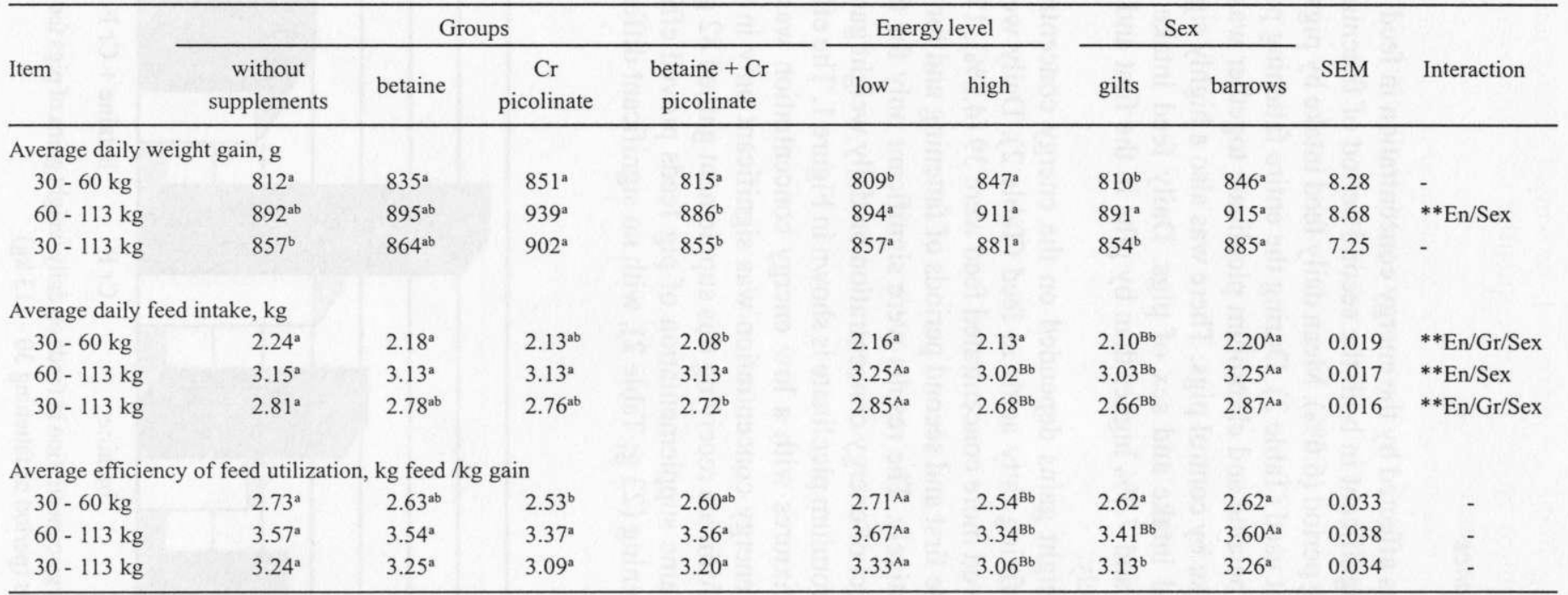

a, b - values in the same rows with different letters differ significantly $(P \leq 0.05)$

$\mathrm{A}, \mathrm{B}$ - values in the same rows with different letters differ significantly $(\mathrm{P} \leq 0.01)$ 
to the control group. In the second period, the weight gains of animals were similar to those in the control group, so consequently, the improvement for the whole fattening period was merely $7 \mathrm{~g}$.

The highest daily weight gains were characteristic of pigs supplemented with chromium picolinate. Differences in weight gains in relation to the control animals observed in the first period of fattening $(39 \mathrm{~g})$ increased to $47 \mathrm{~g}$ in the second. Weight gains for the whole fattening period improved by $45 \mathrm{~g}$ and these differences were significant $(\mathrm{P} \leq 0.05)$. Combined supplementation with betaine and chromium picolinate had no effect on the course of fattening.

Barrows had better weight gains than gilts both in the first period and for the entire period of fattening, and the differences proved significant at $\mathrm{P} \leq 0.05$.

Feed conversion per kilogram weight gain was inversely proportional to mean daily weight gains (Table 2). However, it was most strongly related to the energy concentration in feed, as the differences were highly significant. The increased energy concentration appeared significant only in case of chromium picolinate (Figure 2). Animals receiving this supplement used $0.32 \mathrm{~kg}$ less feed per kilogram body weight gain. Feed conversion was affected to a lesser extent by the supplements used. Significant differences were found only in the first period of fattening between animals given chromium picolinate and controls. Feed conversion was also sex-dependent. This was demonstrated in the second period of fattening, and the differences between barrows and gilts were statistically significant at $\mathrm{P} \leq 0.01$. In the entire fattening period, gilts used $4.2 \%$ less feed per kilogram weight gain than barrows.

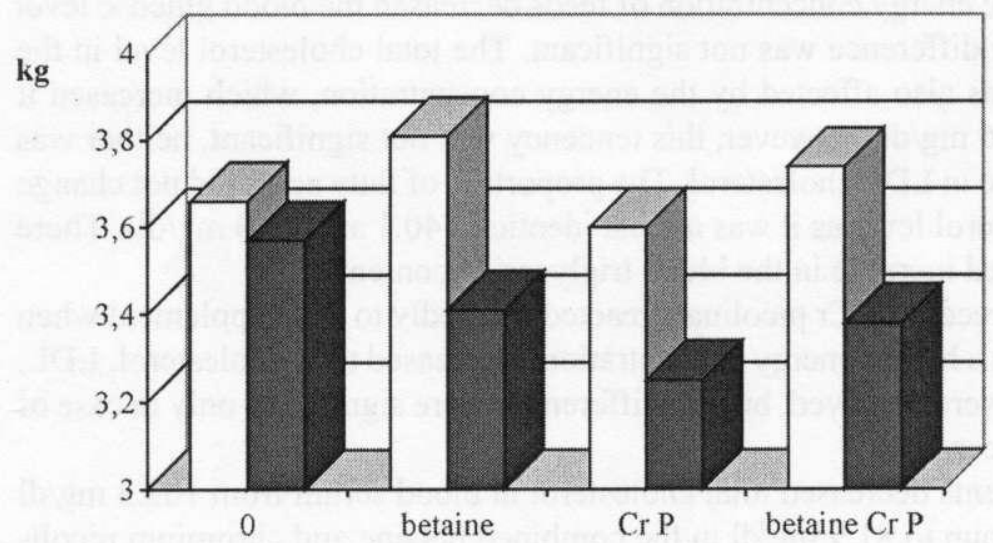

Figure 2. Effect of energy concentration on feed efficiency of pigs treated with betaine or chromium picolinate (period of fattening $30-113 \mathrm{~kg}$ ) 


\section{Post-slaughter carcass evaluation}

Increasing energy concentration of feeds by the addition of post-refining fatty acids did not significantly influence slaughter performance (Table 3). No effect of energy concentration in feed on the efficiency of the studied supplements was observed.

The carcasses of pigs fed betaine- and chromium picolinate-supplemented feeds contained 1.04 and $1.20 \mathrm{~kg}$ more meat of primal cuts, larger loin eye area (4.9 and $9.0 \%)$, better fat-to-lean ratio $(6.2$ and $7.1 \%)$ and higher lean content $(1.9-2.7 \%)$, respectively. Fatteners given chromium picolinate had $0.6 \mathrm{~mm}$ thinner backfat than control animals, and those given betaine, $1 \mathrm{~mm}$ thinner. Significant differences were shown for slaughter yield, lean content of primal cuts, loin eye area, and fatto-lean ratio. In contrast to separate supplementation of betaine and chromium picolinate, their combined supplementation did not improve post-slaughter carcass quality in relation to the control group.

Data in Table 3 indicate that the results of post-slaughter evaluation of carcasses were most strongly related to the sex of animals. Carcasses of gilts were characterized by much better parameters of leanness and lower fatness than carcasses of barrows, the differences between the parameters analysed being significant at $P \leq 0.01$.

\section{Biochemical indicators of blood}

The results of biochemical analysis of pig blood (Table 4) indicate that biochemical parameters were influenced by the supplements, concentration of energy in feeds, and sex of pigs, with all of these factors influencing one another, as confirmed by a statistically significant interaction.

Increasing the energy concentration of feeds decreased the blood glucose level by $5.3 \%$, but the difference was not significant. The total cholesterol level in the blood of pigs was also affected by the energy concentration, which increased it from 87.0 to $93.6 \mathrm{mg} / \mathrm{dl}$. However, this tendency was not significant, neither was the $9.6 \%$ increase in $\mathrm{LDL}$ cholesterol. The proportion of fatty acids did not change the HDL cholesterol level as it was almost identical ( 40.1 and $40.0 \mathrm{mg} / \mathrm{dl}$ ). There was also a marked increase in the blood triglyceride content.

The animals receiving $\mathrm{Cr}$ picolinate reacted markedly to this supplement when used in feed with a higher energy concentration. Decreased total cholesterol, LDL, and lipid levels were observed, but the differences were significant only in case of the last two indices.

The supplements decreased total cholesterol in blood serum from $102.3 \mathrm{mg} / \mathrm{dl}$ in the control group to $81.9 \mathrm{mg} / \mathrm{dl}$ in the combined betaine and chromium picolinate group. A similar effect was noticeable for LDL cholesterol, which was reduced in all groups in relation to the control group. 
TABLE 3

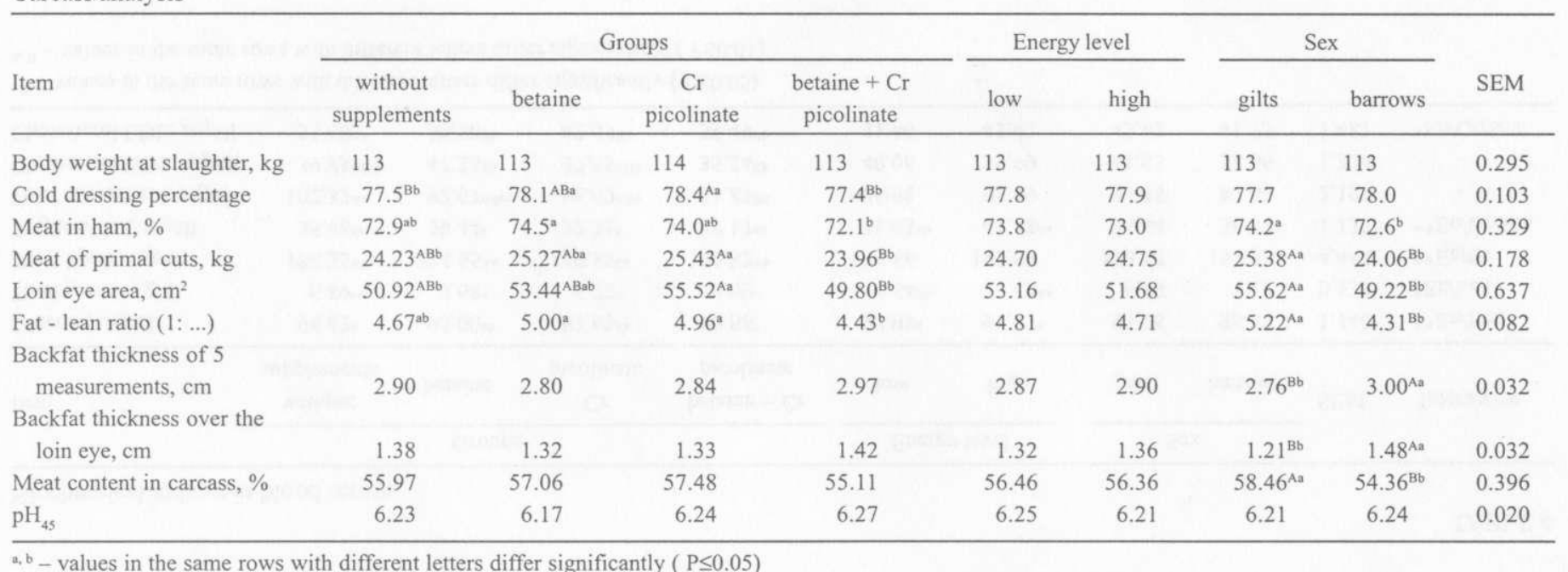

$a, b$ - values in the same rows with different letters differ significantly $(P \leq 0.05)$

A. B - values in the same rows with different letters differ significantly $(P \leq 0.01)$ 
TABLE 4

Biochemical indices in blood serum

\begin{tabular}{|c|c|c|c|c|c|c|c|c|c|c|}
\hline \multirow[b]{2}{*}{ Item } & \multicolumn{4}{|c|}{ Groups } & \multicolumn{2}{|c|}{ Energy level } & \multicolumn{2}{|c|}{ Sex } & \multirow[b]{2}{*}{ SEM } & \multirow[b]{2}{*}{ Interaction } \\
\hline & $\begin{array}{c}\text { without } \\
\text { supplements }\end{array}$ & betaine & $\begin{array}{c}\mathrm{Cr} \\
\text { picolinate }\end{array}$ & $\begin{array}{c}\text { betaine }+\mathrm{Cr} \\
\text { picolinate }\end{array}$ & low & high & gilts & barrows & & \\
\hline Glucose, $\mathrm{mg} / \mathrm{dl}$ & $98.63^{a}$ & $95.00^{\mathrm{ab}}$ & $93.63^{\mathrm{ab}}$ & $90.88^{b}$ & $97.09^{a}$ & $91.97^{\mathrm{b}}$ & 93.28 & 95.78 & 1.140 & $* * \mathrm{En} / \mathrm{Sex}$ \\
\hline Total protein, g/dl & $6.89^{\mathrm{ab}}$ & $7.68^{a}$ & $6.72^{b}$ & $6.69^{b}$ & $6.64^{\mathrm{Bb}}$ & $7.42^{\mathrm{Aa}}$ & 6.89 & 7.13 & 0.138 & ${ }^{*} \mathrm{En} / \mathrm{Sex}$ \\
\hline Total lipids, mg/dl & $184.35^{\mathrm{Bb}}$ & $224.65^{\mathrm{Aa}}$ & $149.85^{\mathrm{Ce}}$ & $190.82^{\mathrm{Bb}}$ & 179.86 & 192.02 & 179.55 & 192.32 & 4.444 & $* * \mathrm{En} / \mathrm{Gr}$ \\
\hline Triglicerides, mg/dl & $35.48^{\mathrm{ab}}$ & $39.44^{a}$ & $32.31^{\mathrm{b}}$ & $38.17^{\mathrm{ab}}$ & $31.63^{\mathrm{Bb}}$ & $41.13^{\mathrm{Aa}}$ & 36.44 & 36.57 & 1.137 & ${ }^{* *} \mathrm{En} / \mathrm{Gr} / \mathrm{Sex}$ \\
\hline Total cholesterol, mg/dl & $102.32^{\mathrm{Aa}}$ & $92.67^{\mathrm{ABab}}$ & $88.69^{\mathrm{ABb}}$ & $81.87^{\mathrm{Bb}}$ & 86.98 & 93.59 & 93.36 & 87.69 & 2.197 & - \\
\hline Cholesterol HDL, mg/dl & $39.73^{\mathrm{ABab}}$ & $47.28^{\mathrm{Aa}}$ & $37.55^{\mathrm{ABb}}$ & $35.24^{\mathrm{Bb}}$ & 40.06 & 39.99 & 41.55 & 38.66 & 1.374 & - \\
\hline Cholesterol LDL, mg/dl & $55.60^{\text {Aa }}$ & $38.56^{\mathrm{Bb}}$ & $42.65^{\mathrm{Bb}}$ & $39.49^{\mathrm{Bb}}$ & 41.46 & 45.42 & 45.43 & 41.75 & 1.481 & ${ }^{*} \mathrm{En} / \mathrm{Gr} / \mathrm{Sex}$ \\
\hline
\end{tabular}

${ }^{a, b}$ - values in the same rows with different letters differ significantly ( $\left.P \leq 0.05\right)$

$\mathrm{A}, \mathrm{B}$ - values in the same rows with different letters differ significantly ( $\mathrm{P} \leq 0.01)$ 


\section{DISCUSSION}

Increasing the concentration of energy in feeds by the use of post-refining fatty acids slightly improved daily weight gains and feed conversion. However, except for chromium picolinate, this had no effect on the efficiency of supplements, as suggested by Haydon et al. (1995) and Matthews et al. (1998). Nevertheless, the energy concentration in the feed mixture influenced feed intake, which significantly depended on both the supplement used and sex of pigs, as confirmed by a highly significant interaction between these factors.

Adding betaine, and especially picolinate, to the feed of pigs had a positive effect on the course of their fattening, the results of post-slaughter evaluation of carcasses, and some biochemical blood parameters. The improvement was more noticeable than that reported by Hanczakowska et al. (1999) and Urbańczyk et al. (1999). This especially concerns betaine, which these authors found to have no effect on improving weight gain. Urbańczyk et al. (1996) found a greater improvement of daily weight gain in pigs supplemented with betaine, which is in agreement with the studies of Smith et al. (1994), Haydon et al. (1995) and Matthews et al. (1998).

The results of the present experiment demonstrated that animals supplemented with chromium picolinate used less feed per kilogram weight gain. A similar trend was observed by Lindemann et al. (1995) and Wenk et al. (1995), while Liarn et al. (1995) observed that feed conversion was slightly worse. The results also showed increased carcass lean content in pigs fed mixtures supplemented with betaine, and especially with chromium picolinate, as found in the majority of the papers mentioned above. However, the decrease in backfat thickness was not so conspicuous as in the experiments of Cadogan et al. (1993), Best (1994), Smith et al. (1994) involving betaine, and in the studies of Lindemann (1995), Grela et al. (1997) and Jacyno et al. (1998), who supplemented pigs with organic chromium compounds. However, it should be pointed out that in some experiments, these supplements not only did not decrease backfat thickness (Mooney and Cromwell, 1995; Wenk et al., 1995; Matthews et al., 1998) but even increased it slightly (Haydon et al., 1995; Lindemann et al., 1995, Mooney and Cromwell, 1999).

The results of the present experiment confirmed the earlier findings of Hanczakowska et al. (1999) and Urbańczyk et al. (1999) who demonstrated lack of synergy between betaine and chromium picolinate for both fattening and slaughter traits. Because those animals that received both of these supplements in feeds did not improve their weight gains or slaughter traits, the combined use of these compounds in pig feeds seems unjustified.

The results of the present experiment also demonstrated a marked effect of sex on fattening and slaughter traits of experimental pigs. Gilts had lower weight gains, used less feed per kilogram body weight gain and had better carcasses than bar- 
rows, which gained much more quickly. The sex of pigs did not have a significant effect on efficiency of the supplements, similarly as in the earlier studies of Hanczakowska et al. (1999) and Urbańczyk et al. (1999).

In summing up the results of the present experiment, betaine and chromium picolinate improved fattening performance and post-slaughter evaluation of carcasses, as reflected partly in the biochemical indicators of blood, especially in a marked decrease of total cholesterol. Betaine and chromium picolinate were ineffective when used together. The efficiency of these supplements, cxcept chromium picolinate given separately, did not depend on the energy concentration of feeds or sex of animals.

\section{REFERENCES}

Allain C.C., Poon L.S., Chan C.S., Richmond W., Fu P.C., 1994. Enzymatic determination of total serum cholesterol. Clin. Chem. 20, 470-475

AOAC, 1990. Association of Official Analytical Chemists. Official Methods of Chemical Analysis. $15^{\text {th }}$ Edition. Arlington, VA

Best P., 1994. Feeding against backfat. Feed Int. 5, 38-40

Betafin Brefing, 1996. Interactions of Betafin with aminoacid. Finnsugar Bioproducts, Inc. 1, 67-70 Cadogan D. J., Campbell R.G., Harrison D., Edwads A.C., 1993. The effects of betaine on growth performance and carcass characteristics of female pigs. In: E.S. Batterham (Editor). Manipulating Pig Production. Australasian Pig Science Association, Attwood, Victoria, (Australia), p. 219

Cera K.R., Schinckel A.P., 1995. Carcass and performance responses to feeding betaine in pigs. J. Anim. Sci. 73, Suppl. 1, 82 (Abstr.)

Cho Y.M., Kim Y.H., Chung W.T., Moon H.K., Kim D.H., Lee J.W., Jang B.G., Chung I.B., Thak T.Y., 1998. Effects of chromium picolinate, barley incorporation and restricted feeding on growth and carcass traits of barrows. In: Proceedings of Contributed Papers, $8^{\text {th }}$ World Conference on Animal Production, Seoul (Korea), Vol, 1, pp. 662-663

Grela E.R., Studziński T., Rabos A., Winiarska A., Dziaduch J., 1997. Effect of a chromium yeast supplement in growing-finishing pig diets on performance, carcass traits and fatty acid composition of adipose tissue. J. Anim. Feed Sci. 6, 87-100

Hanczakowska E., Urbańczyk J, Świątkiewicz M., [999. The efficiency of betaine and organic compounds of chromium in fattening of pigs fed ad libitum or restricted fecding. Ann. Anim. Sci. $26,263-273$

Haydon K.D., Campbell R.G., Prince T.J., 1995. Effect of dietary betaine additions and amino:calorie ratio on performance and carcass traits of finishing pigs. J. Anim. Sci. 73, Suppl. 1, 83 (Abstr.)

Jacyno E., Owsiany J., Szmidke W., 1998. Organic chromium (Bioplex $\mathrm{Cr}$ ) in pig fattening. In: Proceedings of Contributed Papers, $8^{\text {th }}$ World Conference on Animal Production, Seoul (Korea), Vol. 1, 114-115

Lawrence B.V., Schinckel A.P., Adeola O., Cera K., 1995. Performance of pigs fed betaine from 60 to $110 \mathrm{~kg}$ bogy weight. J. Anim. Sci. 73, Suppl. 1, 195 (Abstr.) 
Le Micux F.M., Southem L.L., Binder T.D., 1996. Interactive effects of chromimu tripicolinate, zinc oxide, and (or) betaine on growth performance of weanling pigs. J. Anim. Sci. 74, Suppl. 1, 184 (Abstr.)

Lemme A., Wenk C., 1997. Dosisabängiger Einfluss von Chrom aus Chromhefe auf Mastleistung und Schlachtkörperqualität beim Schwcin. Proc. Soc. Nutr. Physiol. 6

Liam T.F., Chen S.Y., Chen C.L., Wu C.P., 1995. Eflect of various levels of chromium picolinate on growth performance and serum traits of pigs. Nutr. Abstr. Rev., Ser. B. 66, 134-135

Lindemann M.D., Wood C.M., Harper A.F., Kornegay E.T., Anderson R.A., 1995. Dietary chromium picolinate additions improve gain: feed and litter size in reproducing sows. J. Anim. Sci. $73,457-465$

Matthews J.O., Southern L.L., Pontif J.E., Higbie A.D., Bidner T.D., 1998. Interactive effects of betainc, crude protein, and net energy in finishing pigs. J. Anim. Sci. 7, 2444-2455

Mooney K.W., Cromwell G.L., 1995. Effects of dietary chromium picolinate supplementation on growth, carcass characteristics, and accretion rates of carcass tissues in growing-finishing swine. J. Anim. Sci. 73, 3351-3357

Mooney K.W., Cromwell G.L., 1999. Efficacy of chromium picolinate on performance and tissue accretion in pigs with different lean gain potential. J. Anim. Sci. 77, 1188-1198

Mowat D.N., 1993. Organic Cr: New nutrient for stressed animals. Feed Compounder 9, 1-3

Page T.G., Southern L.L., Ward T.L., Thompson D.L. Jr., 1993. Effect of chromium picolinate on growth and serum and carcass traits of growing-finishing pigs. J. Anim. Sci. 71, 656-662

SAS, 1988. SAS User's Guide: Statistics Version 6.03 Ed. SAS Inst. Inc., Cary, NC

Smith J.W. II, Owen K.Q., Nelssen J.L., Goodband R.D., Tokach M.D., Friesen K.G., Lohrmann T.L., Blum S.A., 1994. The effects of dietary carnitine, betaine, and chromium nicotinate supplementation on growth and carcass characteristics in growing-finishing pigs. J. Anim. Sci. 72, Suppl. 1, 274 (Abstr.)

State of Pig Breeding and Results of Pig Performance Test (in Polish), 1995. Research Institute of Animal Production Press, Kraków (Poland), XIV

Tilley J., 1995. Chromium improves carcases. Pig Int. 25 (11), 23 - 24

Urbańczyk J., Hanczakowska E., Gawlik Z., 1996. The effect of betaine supplementation on fattening results and carcass parameters of pigs (in Polish). In: Proceedings of XXVI Scientific Session of Animal Nutrition Committee, Olsztyn (Poland), pp. 227-228

Urbańczyk J., Hanczakowska E., Świątkiewicz M., Sieradzka A., 1998a. The effect of betaine on performance, carcass evaluation and biochemical blood indices of fattening pigs. In: Proccedings of Contributed Papers, $8^{\text {th }}$ World Conference on Animal Production, Seoul (Korea), Vol. 1, 134-135

Urbańczyk J., Hanczakowska E., Świątkiewicz M., Furgał-Dierźuk I., 1998b. The efficency of chromium yeast and chromium picolinate in growing-finishing pigs. In: Proceedings of Contributed Papers, 8th World Conference on Animal Production, Scoul (Korca), Vol.1, 128-129

Urbańczyk J., Hanczakowska E., Świątkiewicz M., 1999. Betaine and organic chromium compounds as feed supplements for fatteners (in Polish). Ann. Warsaw Agr. Univ.-SGGW, Anim. Sci. 36, $133-140$

Warrick G.R., Berdersond J., Alberts J.J., 1982. Dextransulphate - Mg precipitation procedure for quantitation of high-density lipoprotein cholesterol. Clin. Chem. 28, 1379-1388

Wenk C., Gebert S., Pfirter H.P., 1995. Chromzulagen zum Schweinemastfutter: einfluss auf Wachstum und Flcischqualität. Arch. Anim. Nutr. 48, 71-81 


\section{STRESZCZENIE}

\section{Wplyw dodatku betainy i pikolinianu chromu do pasz o różnej koncentracji energii na wyniki tuczu świń}

W doświadczeniu przeprowadzonym na 128 tucznikach, od okoto 30 do $113 \mathrm{~kg}$ masy ciała, podzielonych na 4 grupy, badano wplyw koncentracji energii w paszy na efektywność dodatku betainy lub pikolinianu chromu stosowanych oddziclnie lub łącznie na wyniki tuczu, jakość tusz oraz niektóre wskaźniki biochemiczne krwi.

Zwierzęta otrzymujące mieszanki paszowe o większej koncentracji energii tylko w I okresie tuczu (do $60 \mathrm{~kg}$ m.c.) miały statystycznie istotnie $(\mathrm{P}<0,05)$ wyższe dzienne przyrosty masy ciała niż żywione dietami nisko energetycznymi (847 vs $809 \mathrm{~g}$ ). Wydajność rzeźna nie różniła się między grupami. Wyniki przeprowadzoncgo doświadczenia wykazały, że zastosowane dodatki wpłynçły na poprawę wyników tuczu, zwlaszcza zwierząt otrzymujących pikolinian chromu. W calym okresie tuczu średnic przyrosty m.c. wynosiły po $902 \mathrm{~g}$, podczas gdy w grupie kontrolnej $857 \mathrm{~g}$. Wpływ ten był szczególnie widoczny u tuczników otrzymujących mieszanki o wyższej koncentracji energii. Dodatek pikolinianu chromu wpłynął także na poprawę mięsności i niewielkie obniżenie grubości słoniny. Łączny dodatek betainy i pikolinianu chromu nie wpłynął na poprawę cech tucznych i rzeźnych, lecz spowodował obniżenie zawartości cholesterolu we krwi, szczególnie jego niekorzystnej frakcji LDL, o 9\%.

Loszki rosły wolniej niż wieprzki i miały lepsze wskaźniki oceny poubojowej tusz, niezależnie od zastosowanych dodatków. 